\title{
PENGARUH MODEL LEARNING CYCLE 7E TERHADAP KETERAMPILAN GENERIK SAINS SISWA PADA MATERI PENCEMARAN LINGKUNGAN DI SMP NEGERI 1 BALONGAN INDRAMAYU
}

\author{
Anilia Ratnasari ${ }^{1}$, Risti Maulidah ${ }^{2}$ \\ Universitas Wiralodra, Jl. Ir. H. Djuanda KM 3 Indramayu \\ Email: anilia@ unwir.ac.id ${ }^{1}$, ristymualidah@gmail.com ${ }^{2}$
}

Citasi: Ratnasari, A. dan Maulidah, R. 2018. Pengaruh Model Learning Cycle 7E terhadap Keterampilan Generik Sains Siswa pada Materi Pencemaran Lingkungan di SMP Negeri 1 Balongan Indramayu. Mangifera Edu Vol 3 No. 1, Juli 2018 Hal. 1-15.

\section{ABSTRACT}

Generic science skills of students are still rarely measured by teachers and learning models Learning Cycle $7 E$ was still rarely applied by teachers as a model of learning in schools, then conducted research with the aim to determine the effect of learning cycle model $7 E$ on generic skills science students on environmental pollution material in SMP Negeri 1 Balongan Indramayu. This research was a quantitative research using True-Experimental Design design with Posttest-Only Control Group design. The population in this study is the entire class VII SMP Negeri 1 Balongan indramayu consisting of 11 classes with a total of 352 students. Sampling technique using Probability Sampling technique Cluster Random Sampling type obtained grade VII H as experimental group and grade VII A as control group. Instrument in this research in the form of test of skill of generic science skill student which amounted to 5 problem. Based on the research result, it was found that the average in the experimental class is 74 and the control class is 63,75. With a significant level $(\alpha)=$ 0.05 and degrees of freedom (db) 62 obtained $t_{\text {count }}=28.29$ and $t_{\text {table }}=2,000$. Because $t_{\text {count }}>$ $t_{\text {table, }}$ then reject Ho. This means that the $7 E$ learning cycle model influences the generic skills of students' science on environmental pollution material in SMP Negeri 1 Balongan Indramayu.

Keywords: Learning Cycle 7E Model, Generic Science Skills of Students, Environmental Pollution.

\section{PENDAHULUAN}

Menurut Agus Maimun dalam Nasir dan Tuti Kurniati (2016:131) pembelajaran adalah fakta, konsep, prinsip, dan prosedur pembelajaran yang telah diuji kebenarannya melalui pendekatan ilmiah (behavioristic, kognitivistik, konstruktivistik, perilaku social/social behavior). Sedangkan Aunurrahman (2013:140) mengatakan bahwa keberhasilan proses pembelajaran tidak terlepas dari kemampuan guru mengembangkan model-model pembelajaran yang berorientasi pada peningkatan intensitas keterlibatan siswa secara efektif di dalam proses pembelajaraan.

Berdasarkan kunjungan peneliti ke sekolah, guru masih jarang menerapkan model 
pembelajaran yang berorientasi pada peningkatan intensitas keterlibatan siswa secara efektif di dalam proses pembelajaraan. Meskipun saat ini telah banyak model pembelajaran inovatif yang dikembangkan, namun metode ceramah dan diskusi menjadi pilihan guru untuk menyampaikan materi pembelajaran. Dalam penggunaan metode ceramah guru hanya melatih dan mengukur kemampuan siswa pada ranah kognitif saja sedangkan, ranah afektif dan psikomotor masih jarang dilatih dan diukur oleh guru. Hal ini, sejalan dengan penelitian yang dilakukan oleh Dinda dan Azizah, (2017:163) yang menyatakan bahwa hasil pra penelitian sebanyak 63,64\% siswa menyatakan kegiatan pembelajaran yang dilakukan oleh guru dengan metode ceramah, oleh karena itu perlu adanya inovasi dalam model pembelajaran yang dapat memberikan pengetahuan awal dan mengajak siswa berdiskusi.

Keterampilan generik sains merupakan keterampilan dasar, keterampilan generik sains merupakan salah satu keterampilan yang ada pada diri siswa, dimana keterampilan ini sangat penting untuk dikembangkan oleh guru. Akan tetapi, masih jarang guru yang menyadari akan pentingnya keterampilan tersebut dan tidak banyak guru yang mengukur keterampilan generik sains siswa setelah kegiatan belajar selesai, umumnya guru terbiasa mengukur pada ranah kognitif (C1, dan C2) saja. Di samping itu, guru kurang memberikan contoh-contoh konkrit dalam mengajarkan materi biologi yang ada di lingkungan sekitar yang sering dijumpai siswa. Hal ini membuat siswa cenderung menghapal konsep dalam proses pembelajaran, sebenarnya biologi merupakan ilmu nyata yang dapat dicontohkan langsung dalam lingkungan sekitar, akan tetapi guru tidak mendukung pembelajaran yang dapat mengeksplor langsung pengetahuan yang dimiliki siswa pada kehidupan nyata. Oleh sebab itu, perlu adanya tidak lanjut untuk mengatasi permasalahan tersebut.Pasalnya, keterampilan generik merupakan keterampilan yang berperan penting untuk membekali siswa agar dapat melanjutkan pendidikan yang lebih tinggi.

Menurut Sudarmin (2012) yang dikutip Dissa (2017:1980) keterampilan generik sains adalah kemampuan dalam berpikir dan bertindak sesuai dengan pengetahuan sains yang dimiliki dimana keterampilan ini berkaitan erat dengan sikap ilmiah yang diturunkan dari keterampilan proses sains secara umum. Apabila keterampilan generik sains tidak dilatih akan berakibat pada keterampilan dan kemampuan siswa dalam berpikir dan bertindak sesuai dengan pengetahuan sains yang dimiliki untuk mempelajari berbagai konsep dan menyelesaikan berbagai masalah IPA serta berakibat pula pada proses pembelajaran selanjutnya yang lebih tinggi. Aspek keterampilan generik sains umumnya telah ada pada diri siswa di sekolah, seperti pengamatan langsung. Sedangkan untuk aspek 
lainnya, seperti kesadaran skala, hukum sebab-akibat, pemodelan, hingga membangun konsep masih jarang dimunculkan siswa.

Masalah-masalah ini dapat diatasi dengan menerapkan model Learning Cycle $7 E$ yaitu model pembelajaran yang mengajak siswa untuk menemukan sendiri konsep dalam pembelajarannya. Model Learning Cycle $7 E$ ini merupakan model yang efektif digunakan untuk meningkatkan keterampilan generik sains siswa, karena didalam model ini terdapat tujuh fase yang saling terkait, yaitu memunculkan pemahaman awal siswa(Elicit), pengembangan minat (engage), eksplorasi (explore), penjelasan (explain), menguraikan (elaborate), evaluasi (evaluate), dan memperluas(Extend). Dalam ketujuh fase tersebut siswa dapat mengeksplor pengetahuannya pada kehidupan sehari-hari, sehingga proses pembelajaran menjadi lebih bermakna. Hal ini sejalan dengan penelitian yang dilakukan Dinda dan Azizah (2017:163) yang mengatakan bahwa model pembelajaran Learning Cycle $7 E$ merupakan salah satu model pembelajaran yang berbasis penemuan, karena dalam sintaks pembelajaran Learning Cycle $7 E$ mengarahkan siswa menemukan konsep, hukum, dan teori serta menerapkan dan menjelaskan contoh penerapan konsep yang telah dipelajari, model Learning cycle $7 E$ cocok diterapkan pada pembelajaran yang bersifat hafalan, perhitungan, eksperimen, pemahaman materi, dan penerapan dalam kehidupan sehari-hari.

Anton (2001) dalam Komang dkk (2014:3) mengemukakan bahwa pembelajaran 7E merupakan model pembelajaran yang berlandaskan pandangan konstruktivisme yang memandang bahwa pebelajar mengkonstruksi sendiri pengetahuannya. Pada model pembelajaran 7E siswa mendapat petunjuk-petunjuk seperlunya, dapat berupa pertanyaan pertanyaan yang bersifat membimbing, kemudian sedikit demi sedikit bimbingan dikurangi hingga siswa dapat bekerja mandiri dalam penyelesaian masalah.

Dengan demikian penulis merasa tertarik untuk melakukan penelitian dengan judul "Pengaruh Model Learning Cycle 7E terhadap Keterampilan Generik Sains Siswa Pada Materi Pencemaran Lingkungan Di Kelas VII SMP Negeri 1 Balongan Indramayu”.

\section{METODE}

\section{Waktu Dan Tempat Penelitian}

Tempat penelitian di SMP Negeri 1 Balongan Indramayu dan dilaksanakan pada bulan Februari-Maret 2018, semester genap tahun akademik 2017/2018.

\section{Subjek Penelitian}

Populasi penelitian ini adalah seluruh siswa kelas VII SMP Negeri 1 Balongan http://jurnal.biounwir.ac.id/index.php/mangiferaedu $\mid 3$ 
Indramayu, sampel dipilih dengan menggunakan Probability Sampling jenis Cluster Random Sampling, terpilih kelas VII H sebagai kelas eksperimen dan VII A sebagai kelas kontrol.

\section{Instrumen Penelitian}

Penelitian ini menggunakan instrumen test bentuk pilihan ganda untuk keterampilan generik sains siswa. Semua instrumen sudah dalam kategori valid dan reliabel.

\section{Prosedur Penelitian}

Tahap 1, pada tahap ini studi pendahuluan yang dilakukan peneliti dengan maksud mencari referensi dalam menentukan permasalahan hingga mampu mengidentifikasinya. Dengan demikian peneliti dapat dengan mudah mendapatkan gambaran tentang identifikasi masalah dari judul yang akan diteliti. Tahap 2, peneliti mempersiapkan segala perangkat penelitian dengan membuat instrumen penelitian, baik berupa silabus, rencana pelaksanaan pembelajaran (rpp), kisi-kisi soal dan rubrik penilaian, sebelum digunakan di lapangan instrumen penelitan ini sudah divalidasi dan diujicobakan. Tahap 3, instrumen penelitian digunakan di kelas eksperimenyang menggunakan model Learning Cycle $7 E$ dan kelas kontrol yang menggunakan metode diskusi pada akhir pembelajaran sebagai posttest. Tahap 4, data yang diperoleh di lapangan kemudian di analisis untuk mengetahui pengaruh model Learning Cycle $7 E$ terhadap keterampilan generik sains siswa. Tahap 5, setelah data dianalisis, maka diperoleh hasil penelitian. Hasil penelitian dijelaskan secara terperinci sehingga tidak terjadi ketimpangan. Tahap 6, hasil penelitian dapat disimpulkan sebagai tahap akhir penelitian.

\section{Analisis Dan Interpretasi Data}

Analisis data tes keterampilan generik sains siswa dianalisis secara kuantitatif dengan menghitung kesamaan dua rata-rata (uji t) anatara kelas yang menggunakan model Learning Cycle $7 E$ dan kelas kontrol yang menggunakan metode diskusi.

\section{HASIL DAN PEMBAHASAN}

Distribusi frekuensi kelas eksperimen yang menggunakan Model Learning Cycle $7 E$ dan kelas kontrol yang menggunakan Metode Diskusi dapat dilihat pada Tabel 1. 
Tabel 1. Distribusi frekuensi kelas eksperimen yang menggunakan Model Learning Cycle $7 \boldsymbol{E}$ dan kelas kontrol yang menggunakan Metode Diskusi

Kelas eksperimen yang menggunakan Model Learning Cycle $7 E$

\section{Kelas kontrol yang menggunakan Metode Diskusi}

\begin{tabular}{cccccc}
\hline Kelas Interval & Batas Kelas & Fi & Kelas Interval & Batas Kelas & Fi \\
$\mathbf{5 0}-\mathbf{5 7}$ & $49,5-57,5$ & 5 & $45-51$ & $44,5-51,5$ & 4 \\
$\mathbf{5 8}-\mathbf{6 5}$ & $57,5-65,5$ & 6 & $52-58$ & $51,5-58,5$ & 3 \\
$\mathbf{6 6}-\mathbf{7 3}$ & $65,5-73,5$ & 1 & $59-65$ & $58,5-65,5$ & 15 \\
$\mathbf{7 4 - 8 1}$ & $73,5-81,5$ & 9 & $66-72$ & $65,5-72,5$ & 3 \\
$\mathbf{8 2}-\mathbf{8 9}$ & $81,5-89,5$ & 8 & $73-79$ & $72,5-79,5$ & 5 \\
$\mathbf{9 0}-\mathbf{9 7}$ & $89,5-97,5$ & 3 & $80-86$ & $79,5-89,5$ & 2 \\
& Jumlah $\left(\sum\right)$ & $\mathbf{3 2}$ & & Jumlah $\left(\sum\right)$ & 32 \\
\hline
\end{tabular}

Tabel 1. dapat dijelaskan bahwa dari 32 siswa hasil keterampilan generik sains siswa pada kelas yang menggunakan model learning cycle $7 E$ (kelas eksperimen) yang mendapatkan nilai terendah pada interval 50-57 berjumlah 5 siswa, yang mendapatkan nilai tertinggi pada interval 90-97 berjumlah 3 siswa, sedangkan frekuensi terbanyak yaitu berjumlah 9 siswa pada interval 74-81. Sedangkan, kelas yang menggunakan metode diskusi dengan jumlah siswa sebanyak 32 yang mendapatkan nilai terendah pada interval 45-51 berjumlah 4 siswa, yang mendapatkan nilai tertinggi pada interval 80-86 berjumlah 2 siswa, sedangkan frekuensi terbanyak yaitu berjumlah 15 siswa pada interval 59-65. Adapun persentase ketercapaian keterampilan generik sains siswa setiap indikator pada kelas eksperimen yang menggunakan model learning cycle 7E dan kelas kontrol yang menggunakan metode diskusi dapat dilihat pada Gambar 1. 


\section{Jurnal Mangifera Edu, Volume 3, Nomor 1, Juli 2018, Halaman 1-15}

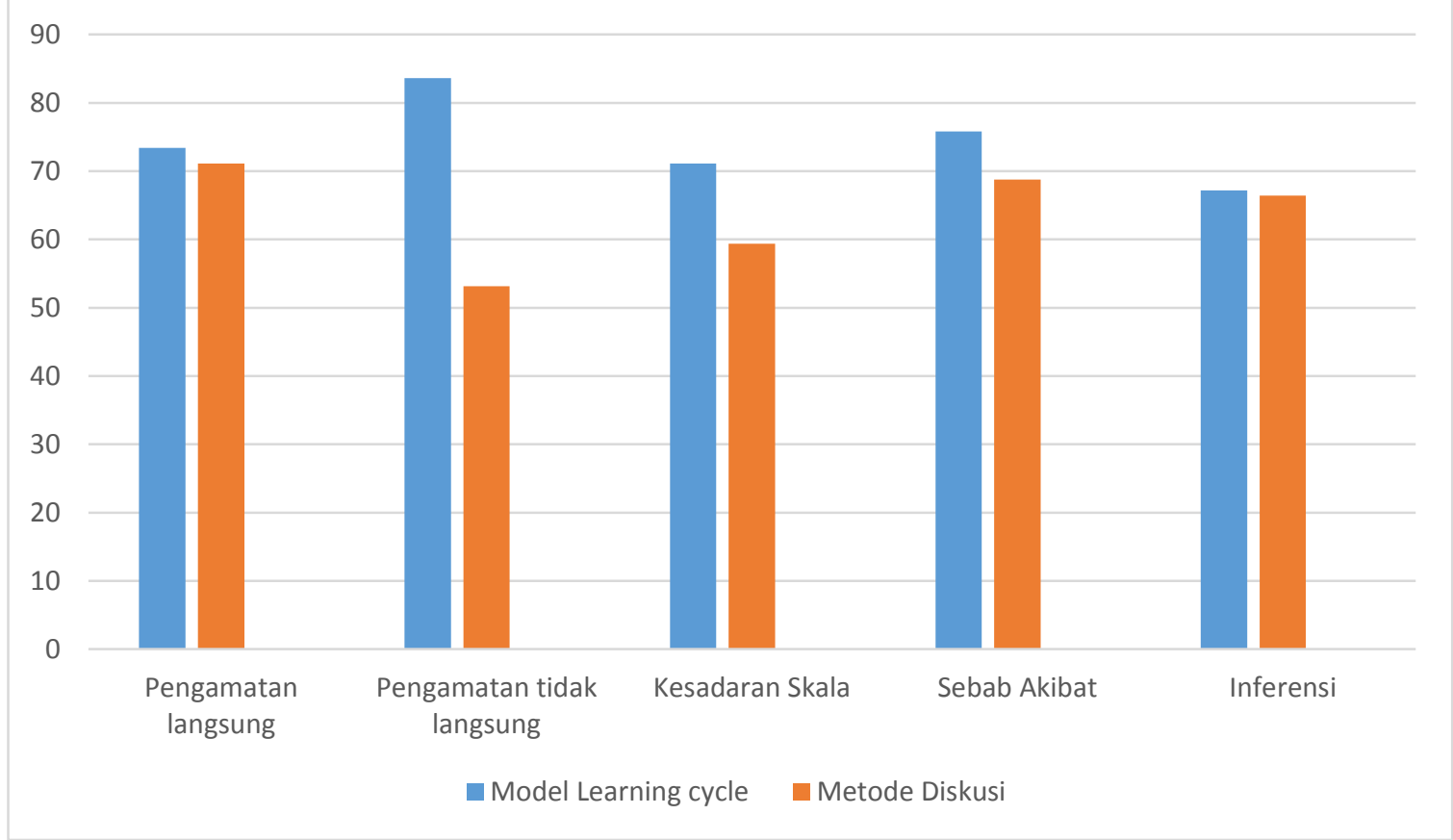

Gambar 1. menunjukkan bahwa kelas yang menggunakan model learning cycle $7 E$ memiliki perbedaan yang signifikan daripada kelas yang menggunakan metode diskusi, yaitu keterampilan generik sains siswa pada kelas yang menggunakan model learning cycle $7 E$ lebih tinggi daripada kelas yang menggunakan metode diskusi. Hasil uji-t dapat dilihat pada Tabel 2.

Tabel 2. Hasil Uji Kesamaan Dua Rata-Rata (Uji-t)

\begin{tabular}{|l|c|c|c|c|c|}
\hline \multicolumn{1}{|c|}{ Kelas } & Rata-rata & Varians & $\mathbf{S}_{\text {gab }}$ & $\mathbf{t}_{\text {hitung }}$ & $\mathbf{t}_{\text {tabel }}$ \\
\cline { 1 - 3 } $\begin{array}{l}\text { Menggunakan } \\
\begin{array}{l}\text { Myclel Learning } \\
\text { CyE }\end{array}\end{array}$ & 74 & 173,18 & 11,50 & 28,29 & 2,000 \\
\cline { 1 - 3 } $\begin{array}{l}\text { Menggunakan } \\
\text { metode diskusi }\end{array}$ & 63,75 & 91,58 & & & \\
\hline
\end{tabular}

Tabel 2. hasil nilai keterampilan generik sains siswa diperoleh nilai thitung sebesar 28,29 sedangkan $t_{\text {tabel }}$ pada taraf signifikan 0,05 sebesar 2,000. Karena $t_{\text {hitung }}>t_{\text {tabel }}$. Artinya, Ho ditolak dan Ha diterima.

Berdasarkan Tabel 1. hasil keterampilan generik sains siswa yang menggunakan model learning cycle 7E yang diterapkan pada kelas VII H dengan jumlah 32 siswa menunjukkan nilai terendah pada interval $50-57$ berjumlah 5 siswa. Artinya, ke 5 siswa tersebut mempunyai keterampilan generik sains siswa cukup baik, dimana ke 5 siswa tersebut dapat menjelaskan penyebab terjadinya pencemaran, akan tetapi kurang lengkap, siswa belum dapat menyebutkan indikator air dikatakan tercemar dengan lengkap, siswa 
dapat membedakan air yang tercemar dengan air yang tidak tercemar dengan perbandingan volume air yang diberikan satu bungkus detergen atau siswa hanya dapat menjelaskan alasannya saja, kurang dapat menjelaskan penyebab dan dampaknya air tercemar, belum dapat memecahkan masalah pencemaran air. Hal ini disebabkan pada saat kegiatan belajar ke 5 siswa tersebut kurang memperhatikan, tidak melaksanakan tugas yang diberikan oleh guru dengan baik, dan kurang berperan aktif, serta siswa tidak berkonsentrasi dalam kegiatan inti proses pembelajaran, ke 5 siswa tersebut cenderung bermain sendiri dengan teman satu kelompoknya, sehingga ke 5 siswa tersebut mendapatkan nilai paling rendah diantara siswa lainnya.

Sebagaimana yang dikatakan Aunurrahman (2014:181) "Kesulitan berkonsentrasi merupakan indikator adanya masalah belajar yang dihadapi siswa, karena hal itu akan menjadi kendala di dalam mencapai hasil belajar yang diharapkan". Sedangkan pada kegiatan belajar menggunakan model learning cycle 7E menuntut siswa untuk berperan aktif dalam setiap fase (tahap) kegiatan pembelajaran agar hasil yang didapatkan sesuai dengan yang diharapkan. Sebagaimana yang dikatakan Fajaroh dan Dasna (2005) yang dikutip Apriani (2012:2) berdasarkan tahapan-tahapan dalam metode pembelajaran bersiklus, diharapkan siswa tidak hanya mendengar keterangan guru, tetapi dapat berperan aktif untuk menggali dan memperkaya pemahaman mereka terhadap konsep-konsep yang dipelajari. Mita mirjanah (2017:24) juga mengatakan pembelajaran dengan menggunakan model siklus belajar Learning cycle $7 E$ menuntut siswa aktif karena di dalam tahapan-tahapan model ini setiap tahapannya melibatkan siswa sepenuhnya.

Berdasarkan Tabel 1. hasil nilai keterampilan generik sains siswa yang menggunakan model learning cycle 7E yang diterapkan pada kelas VII H dengan jumlah siswa sebanyak 32 siswa menunjukkan yang mendapatkan nilai tertinggi pada interval 90-97 berjumlah 3 siswa. Artinya, ke 3 siswa tersebut mempunyai keterampilan generik sains siswa sangat baik, dimana ke 3 siswa tersebut dapat menjelaskan penyebab terjadinya pencemaran air, dapat menyebutkan indikator air dikatakan tercemar, dapat menjelaskan air tercemar dan air yang tidak tercemar dengan perbandingan volume air yang diberikan satu bungkus detergen, dapat menjelaskan penyebab dan dampaknya air tercemar, siswa dapat menjelaskan penyebab terjadinya pencemaran dan dampaknya bagi ekosistem. Akan tetapi, ke 3 siswa tersebut kurang dapat memecahkan masalah pencemaran air.

Hal ini dikarenakan ketika proses pembelajaran siswa tersebut memperhatikan saat proses pembelajaran berlangsung, melaksanakan tugas yang diberikan oleh guru dengan http://jurnal.biounwir.ac.id/index.php/mangiferaedu $\mid 7$ 
baik, siswa berperan aktif, dan berkonsentrasi dalam kegiatan inti proses pembelajaran, serta siswa terlibat langsung dalam proses pembelajaran, sehingga ke 3 siswa tersebut dapat memperoleh nilai paling tinggi diantara siswa lainnya. Anurrahman (2014:121) mengatakan "Keterlibatan langsung siswa didalam prosses pembelajaran memiliki intensitas keaktifan yang lebih tinggi. Dalam keadaan ini siswa tidak hanya sekedar aktif mendengar, mengamati, dan mengikuti, akan tetapi terlibat langsung di dalam melaksanakan suatu percobaan, peragaan atau mendemostrasikan sesuatu".

Pembelajaran menggunakan model learning cycle $7 E$ siswa dituntut berperan aktif dalam proses kegiatan pembelajaran, sehingga siswa dapat mencapai kompetensi pembelajaran sesuai dengan yang diharapkan. Hal tersebut sesuai dengan pendapat Ngalimun (2017:247) yang mengatakan bahwa Learning cycle merupakan rangkaian tahaptahap kegiatan (fase) yang diorganisasi sedemikian rupa sehingga pebelajar dapat menguasai kompetensi-kompetensi yang harus dicapai dalam pembelajaran dengan jalan berperan aktif.

Berdasarkan Tabel 1. hasil keterampilan generik sains siswa kelas yang menggunakan metode diskusi diterapkan pada kelas VII A dengan jumlah siswa sebanyak 32 yang mendapatkan nilai terendah pada interval $45-51$ berjumlah 4 siswa. Artinya, ke 4 siswa tersebut mempunyai keterampilan generik sains siswa cukup baik. Dimana ke 4 siswa tersebut kurang dapat menjelaskan penyebab terjadinya pencemaran air, siswa belum dapat menyebutkan indikator air dikatakan tercemar dengan lengkap, siswa hanya dapat membedakan air yang tercemar dengan air yang tidak tercemar dengan perbandingan volume air yang diberikan satu bungkus detergen atau siswa hanya dapat menjelaskan alasannya saja, siswa kurang dapat menjelaskan penyebab terjadinya pencemaran dan dampaknya bagi ekosistem, dan siswa tersebut kurang dapat memecahkan masalah pencemaran air. Hal ini disebabkan ketika proses pembelajaran siswa tersebut kurang memahami, kurang memperhatikan, tidak melaksanakan tugas yang diberikan oleh guru dengan baik, dan kurang terlibat dalam pembelajaran serta sikap siswa dalam proses belajar, sehingga ke 4 siswa tersebut nilainya rendah. Hal ini didukung pendapat Suriansyah, dkk (2014:9) mengatakan bahwa siswa yang tergolong pada kemampuan rendah ditandai dengan kurangnya motivasi belajar, tidak adanya keseriusan dalam mengikuti pelajaran, termasuk menyelesaikan tugas, dan lain sebagainya.

Hasil keterampilan generik sains siswa yang menggunakan metode diskusi diterapkan pada kelas VII A dengan jumlah siswa sebanyak 32 yang mendapatkan nilai tertinggi pada interval $80-86$ berjumlah 2 siswa.Artinya, ke 2 siswa tersebut mempunyai 
keterampilan generik sains siswa cukup baik, dimana ke dua siswa tersebut dapat menjelaskan penyebab terjadinya pencemaran air, siswa kurang dapat menyebutkan indikator air dikatakan tercemar dengan lengkap, siswa hanya dapat membedakan air yang tercemar dengan air yang tidak tercemar dengan perbandingan volume air yang diberikan satu bungkus detergen atau siswa hanya dapat menjelaskan alasannya saja, siswa kurang dapat menjelaskan penyebab terjadinya pencemaran dan dampaknya bagi ekosistem, dan ke dua siswa tersebut dapat memecahkan masalah pencemaran air. Hal ini dikarenakan ketika proses pembelajaran siswa tersebut memperhatikan, melaksanakan tugas yang diberikan oleh guru dengan baik, dan siswa berperan aktif dalam kegiatan pembelajaran, sehingga ke dua siswa tersebut mendapatkan nilai tertinggi diantara siswa lainnya.

Sesuai dengan pendapat Suriansyah, dkk (2014:9) mengatakan bahwa siswa yang berkemampuan tinggi biasanya ditunjukkan oleh motivasi yang tinggi dalam belajar, perhatian, dan keseriusan dalam mengikuti pelajaran dan lain-lain. Piaget yang dikutip oleh Trianto (2010:72) bahwa kegiatan berdiskusi dapat membantu memperjelas pemikiran, yang pada akhirnya membuat pemikiran itu menjadi lebih logis. Sejalan dengan pendapat Aunurrahman (20114:36) bahwa "Kegiatan belajar merupakan kegiatan yang disengaja atau direncanakan oleh pembelajar sendiri dalam bentuk suatu aktivitas tertentu. Aktivitas ini menunjuk pada keaktifan seseorang dalam melakukan sesuatu kegiatan tertentu, baik pada aspek-aspek jasmaniah maupun aspek mental yang memungkinkan terjadinya perubahan pada dirinya".

Dalam penelitian ini, peneliti mengukur 5 indikator keterampilan generik sains siswa yaitu pengamatan langsung, pengamatan tidak langsung, kesadaran skala, sebab akibat, dan inferensi. Berikut ini akan dijabarkan secara rinci hasil setiap indikator keterampilan generik sains siswa pada kelas yang menggunakan model learning cycle $7 E$ dan kelas yang menggunakan metode diskusi berdasarkan pada Gambar 1.

Berdasarkan pada Gambar 1. terlihat bahwa indikator pengamatan langsung pada kelas yang menggunakan model learning cycle $7 E$ lebih tinggi daripada kelas yang menggunakan metode diskusi. Kelas yang menggunakan model learning cycle $7 E$ mendapatkan persentase sebesar $73,44 \%$, sedangkan kelas yang menggunakan metode diskusi yaitu sebesar 71,09\%. Artinya, pada kelas yang menggunakan model learning cycle $7 E$ lebih memahami indikator pengamatan langsung daripada kelas yang menggunakan metode diskusi, dimana pada indikator pengamatan langsung ini siswa diminta menyelidiki penyebab terjadinya pencemaran air. 
Hal tersebut dikarenakan pada kelas yang menggunakan model learning cycle $7 E$ indikator pengamatan langsung dapat dimunculkan pada tahap explore, selain pada tahap explore indikator pengamatan langsung juga dapat dimunculkan pada tahap elicit dan engage. Eisankraft (2003:57) mengatakan "Pada tahap elicit guru mendatangkan pengetahuan awal siswa dengan memberikan pertanyaan tentang kejadian sehari-hari berdasarkan pengamatan langsung. Kemudian pada tahap engage, siswa saling memberikan informasi dan pengalaman terkait pertanyaan awal pada tahap elicit serta melibatkan siswa melalui diskusi dan demonstrasi”.

Selanjutnya masih pada Gambar 1. pada indikator pengamatan langsung kelas yang mengunakan metode diskusi mendapatkan 71,09\%. Artinya keterampilan generik sains siswa indikator pengamatan langsung pada kelas yang menggunakan metode diskusi termasuk kategori cukup tinggi. Hal ini dikarenakan siswa tidak dilibatkan secara langsug dalam proses pembelajaran, siswa hanya diminta untuk memecahkan masalah pada lembar kerja yang telah diberikan oleh guru yang kemudian didiskusikan. Selain itu, guru tidak memberikan contoh konkrit kepada siswa. Akan tetapi, guru hanya menjelaskan sesuai konsep dan hasil diskusi dari siswa. Helmiati (2016:67) mengatakan bahwa dalam kegiatan diskusi guru mengungkapkan kembali (memarafrasekan) apa yang dikatakan oleh seorang siswa sehingga siswa tersebut merasa bahwa pertanyaan atau komentarnya dipahami dan siswa lain dapat mendengar ringkasan apa yang telah ditanyakan. Pasaribu dan Simandjuntak (2005:86) berpendapat bahwa metode Diskusi adalah cara penyampaian informasi dan pengetahuan kepada peserta didik secara lisan, atau tertulis.

Indikator pengamatan tidak langsung pada kelas yang menggunakan model learning cycle $7 E$ mendapatkan nilai persentase paling tinggi yaitu sebesar $83,59 \%$ diantara indikator keterampilan generik sains siswa yang lainnya. Akan tetapi, pada kelas yang menggunakan metode diskusi persentase indikator pengamatan tidak langsung justru paling rendah diantara indikator lainnya yaitu sebesar 53,12\%. Artinya, siswa pada kelas yang menggunakan model learning cycle 7E lebih memahami pengamatan tidak langsung daripada kelas yang menggunakan metode diskusi, dimana pada kedua kelas tersebut siswadiminta untuk menyebutkan indikator air dikatakan tercemar berdasarkan parameternya.

Hal ini dikarenakan pada kelas yang menggunakan model learning cycle $7 E$ indikator pengamatan tidak langsung siswa dilibatkan langsung melalui kegiatan praktikum (tahap eksplore). Sebagaimana yang dikatakan Eisankraft (2003:58) "Pada tahap explore, memberikan kesempatan bagi siswa untuk mengamati, mencatat data, mengisolasi variabel, 
merancang dan merencanakan eksperimen, membuat grafik, menafsirkan hasil, mengembangkan hipotesis, dan mengatur temuan mereka. Guru dapat memberikan umpan balik, dan menilai pemahaman".Diperkuat dengan pendapat Ebert II, dkk (2011:20) yang mengatakan bahwa model learning cycle $7 E$ merupakan model pembelajaran berlandaskan kontruktivisme yang memandang siswa mengkontruksi sendiri pengetahuannya. Pada tahap explorasi, pebelajar diberi kesempatan untuk memanfaatkan panca inderanya semaksimal mungkin dalam berinteraksi dengan lingkungan melalui kegiatan-kegiatan seperti praktikum, menganalisis artikel, mendiskusikan fenomena alam, mengamati fenomena alam atau perilaku sosial, dan lain-lain.

Keterampilan generik sains siswa indikator pengamatan tidak langsung pada kelas yang menggunakan metode diskusi $(53,12 \%)$. Artinya, indikator pengamatan tidak langsung pada kelas yang menggunakan metode diskusi termasuk kategori rendah. Hal ini dikarenakan dalam proses pembelajaran siswa hanya diminta berdiskusi mengenai materi yang akan dipelajari saja, sehingga keterampilan pengamatan tidak langsung tidak muncul pada saat kegiatan inti proses pembelajaran. Djajadisastra (1992:10) mengatakan metode diskusi diartikan sebagai siasat "Penyampaian bahan pengajaran yang melibatkan peserta didik yang bersifat untuk membicarakan dan menentukan alternative pemecahan suatu topic bahasan yang bersifat problematif'. Guru, peserta didik, atau kelompok peserta didik memiliki perhatian yang sama terhadap topik yang dibicarakan dalam diskusi.

Berdasarkan pada Gambar 1. terlihat bahwa keterampilan generik sains pada indikator kesadaran skala pada kelas yang menggunakan model learning cycle $7 E$ memiliki persentase keterampilan generik sains siswa lebih tinggi yaitu sebesar 71,09\%, daripada indikator kesadaran skala pada kelas yang menggunakan metode diskusi yaitu sebesar $59,38 \%$. Artinya, siswa pada kelas yang menggunakan model learning cycle $7 E$ memiliki kepekaan lebih tinggi terhadap kesadaran skala daripada kelas yang menggunakan metode diskusi, dimana pada indikator kesadaran skala siswa diminta untuk membandingkan air manakah yang termasuk air tercemar antara air jernih yang berada didalam ember dengan air jernih yang berada disungai kemudian diberikan satu bungkus detergen. Hal ini dikarenakan indikator kesadaran skala pada kelas yang menggunakan model learning cycle $7 E$ dapat dimunculkan pada tahap explore.

Pada tahap explore siswa dapat merencanakan dan merancang praktikum diantaranya yaitu menyiapkan alat dan bahan praktikum serta mengukur volume air pada setiap perlakuan yang berbeda. Sebagaimana yang dikatakan Sudarmin (2012:35) yang http://jurnal.biounwir.ac.id/index.php/mangiferaedu $\mid 11$ 
mengatakan bahwa keterampilan kesadaran tentang skala dapat dikembangkan saat praktikum melalui kegiatan pembuatan larutan seperti pengukuran volume pelarut dan penimbangan zat terlarut dengan penimbangan zat terlarut dengan menggunakan alat ukur.

Masih pada Gambar 1. indikator kesadaran skala, pada kelas yang menggunakan metode diskusi mendapatkan persentase 59,38\%. Artinya, keterampilan generik sains siswa indikator kesadaran skala pada kelas yang menggunakan metode diskusitermasuk kategori sedang. Hal ini dikarenakan siswa hanya melakukan diskusi dari lembar kerja yang diberikan oleh guru, selebihnya siswa hanya mendengarkan penjelasan guru berdasarkan argumen dari siswa.Sebagaimana yang dikatakan Helmiati (2016:79) bahwa kegiatan diskusi dapat membantu siswa belajar menilai logika, bukti, dan argumentasi (hujjah), baik pendapatnya sendiri maupun pendapat orang lain. Dalam kegiatan diskusi tidak semua siswa berperan aktif, Engkoswara (1984:53) mengatakan dalam metode diskusi biasanya ada siswa yang memborong pembicaraan atau aktif dan ada siswa yang pasif.

Berdasarkan pada Gambar 1. terlihat bahwa keterampilan generik sains pada indikator sebab akibat pada kelas yang mnggunakan model learning cycle $7 E$ memiliki persentase lebih tinggi yaitu sebesar $75,78 \%$, daripada indikator sebab akibat pada kelas Pengamatan tidak langsungyang menggunakan metode diskusi termasuk kategori sedang yaitu $68,75 \%$. Artinya, kelas yang menggunakan model learning cycle $7 E$ lebih memahami penyebab dan dampak pencemaran air bagi ekosistem. Hal tersebut dikarenakan pada kelas yang menggunakan model learning cycle $7 E$ indikator sebab akibat dapat dimunculkan pada tahap extend dimanasiswa dapat menghubungkan konsep yang telah dipelajari dengan konsep lain. Eisankraft (2003:59) mengatakan bahwa "Pada tahap extend bertujuan untuk berfikir, mencari, menemukan dan menjelaskan contoh penerapan konsep yang telah dipelajari bahkan kegiatan ini dapat merangsang siswa untuk mencari hubungan konsep yang mereka pelajari dengan konsep lain yang sudah atau belum mereka pelajari”. Dalam hal ini siswa dapat menghubungkan konsep pencemaran air dengan konsep ekosistem.

Masih pada Gambar 1. indikator sebab akibat, pada kelas yang menggunakan metode diskusi mendapatkan persentase $68,75 \%$. Artinya, keterampilan generik sans siswa indikator sebab akibat pada kelas yang menggunakan metode diskusi termasuk kategori sedang. Hal ini dikarenakan keterampilan sebab akibat dilatihkan kepada siswa pada kegiatan diskusi saja, sebagaimana yang dikatakan Karo-karo, dkk (1998:25) Metode diskusi adalah suatu cara penyajian bahan pelajaran dengan menugaskan peserta didik atau kelompok belajara untuk melaksanakan percakapan ilmiah untuk mencari kebenaran dalam rangka http://jurnal.biounwir.ac.id/index.php/mangiferaedu $\mid 12$ 
mewujudkan tujuan pengajaran. Selain itu guru tidak memberikan penjelasan yang lebih luas terkait dengan pembelajaran yang sedang dipelajari dan hanya memberikan penjelasan kepada siswa sesuai konsep saja.

Berdasarkan Gambar 1. keterampilan generik sains siswa pada indikator inferensi terlihat pada kelas yang menggunakan model learning cycle $7 E$ lebih tinggi yaitu $67,19 \%$ daripada kelas yang menggunakan metode diskusi yaitu 66,41\%. Artinya, kedua kelas tersebut kurang mampu memecahkan masalah pencemaran air. Menurut Brotosiswojo (2001) dalam Apriani (2012:6), keterampilan generik inferensia logika dikategorikan sebagai keterampilan generik yang sulit dikembangkan.

Hal ini dikarenakan pada kelas yang menggunakan model learning cycle $7 E$ keterampilan inferensi dilatihkan kepada siswa pada tahap elaborate. Eisankraft (2003:58) mengatakan bahwa pada fase elaborateguru memberi kesempatan bagi siswa untuk menerapkan pengetahuan mereka ke domain baru, yang mungkin mencakup mengemukakan pertanyaan dan hipotesis baru untuk dijelajahi. Fase ini juga mencakup masalah numerik terkait yang harus dipecahkan oleh siswa. Hal ini diperkuat dengan pendapat Brown dan Abell (2007:59) mengatakan bahwa pendekatan siklus belajar membantu siswa memahami ide-ide ilmiah, meningkatkan penalaran ilmiah, dan keterlibatan siswa di dalam kelas.

Masih pada Gambar 1. indikator inferensi, pada kelas yang menggunakan metode diskusi mendapatkan persentase $66,41 \%$. Artinya, keterampilan generik sains pada indikator inferensi pada kelas yang menggunakan metode diskusi termasuk kategori sedang. Hal ini dikarenakan keterampilan inferensi dilatihkan pada kegiatan diskusi. Suryosubroto (1997:179) yang mengatakan bahwa metode diskusi adalah adalah suatu cara penyajian bahan pengajaran dengan guru memberikan kesempatan kepada siswa atau kelompokkelompok untuk mengadakan perbincangan ilmiah guna mengumpulkan pendapat, membuat kesimpulan atau menyusun ke berbagai alternatif pemecahan suatu masalah.

Berdasarkan Tabel 2. hasil analisis data kedua sampel menunjukkan perbedaan ratarata keterampilan generik sains siwa pada kelas yang menggunakan model learning cycle $7 E$ menunjukkan nilai rata-rata yang didapat lebih tinggi yaitu sebesar 74 daripada nilai ratarata kelasyang menggunakan metode diskusi yaitu 63,75. Artinya, keterampilan generik sains siswa pada kelas yang menggunakan model learning cycle $7 E$ lebih baik dari pada kelas yag menggunakan metode diskusi. Hal ini dikarenakan pada model learning cycle $7 E$ siswa dilatih untuk mencari pengatahuan sendiri dari apa yang akan mereka pelajari dan dapat berperan aktif dalam setiap tahapan model learning cycle $7 E$. 
Sebagaimana yang dikatakan Gerber, dkk dalam Ebert II dkk (2011:21) bahwa dengan menggunakan model learning cycle $7 E$ siswa memiliki kemampuan penalaran yang lebih canggih, dan kinerja keterampilan proses yang lebih baik. Sejalan dengan pendapat Sutrisno, dkk (2012)yang dikutip Mita Mirjanah, dkk (2017:20) mengatakan bahwa model pembelajaran Learning Cycle $7 E$ dapat merangsang siswa untuk mengingat kembali materi pelajaran yang telah mereka dapatkan sebelumnya; memberikan motivasi kepada siswa untuk menjadi lebih aktif dan menambah rasa ingin tahu siswa; melatih siswa belajar menemukan konsep melalui eksperimen; melatih siswa untuk menyampaikan secara lisan konsep yang telah mereka pelajari; memberikan kesempatan kepada siswa untuk berpikir, mencari, menemukan dan menjelaskan contoh penerapan konsep yang telah dipelajari.

\section{DAFTAR PUSTAKA}

Apriani, D.N., Saptorini, Sri N. 2012. Pembelajaran Learning Cycle 7E Terhadap Hasil Belajar dan Keterampilan Generik Sains siswa. Chem in Edu 2 (1): 1-8.

Aunurrahman. 2014. Belajar dan Pembelajaran. Bandung: Alfabeta.

Djajadisastra, Y. 1992. Pendidikan Anak Berkesulitan Belajar. Jakarta: Rineka Cipta.

Eisenkraft, A. Expanding The 5E Model: A Proposed 7E Model Emphasizes"Transfer Of Learning" And The Importance Of Eliciting Prior Understanding. National Science Teachers Association (NSTA). The ScienceTeacher, 70 (6): 56-59.

Ebert II,E.S., dkk. (2011). The Educator's Field Guide: From Organization To Assessment (and Everything in Between). United states of america: corwin press.

Helmiati. 2016. Model Pembelajaran. Yogyakarta: Aswaja Pressindo.

Karo-karo, dkk. 1998. Pengantar Kepemimpinan Pendidikan. Jakarta : Alda.

Marek, E.A. 2008. Why The Learning Cycle. Journal Of Elementari Science Education, 20 (3): 63-69.

Mirjanah, M., Hastuti, S.P., dan Priyayi, D.F. 2017. Peningkatan Aktivitas Dan Hasil Belajar Siswa Melalui Penerapan Model Learning Cycle 7e (Lc 7e) Pada Pembelajaran Biologi. Varia Pendidikan, 29, (1): 18-27

Nasir dan Kurniati T. 2016. Profesi Keguruan. Yogyakarta: K-media.

Ngalimun. 2017. Strategi Pembelajaran. Yogyakarta: Penerbit Parama Ilmu. Suriansyah, A., dkk. 2014. Strategi pembelajaran. Jakarta: Rajawali Press.

Octafianellis, D.F. dan Sudarmin. 2017. Pembelajaran PQ4R Berpendekatan Vak Untuk http://jurnal.biounwir.ac.id/index.php/mangiferaedu $\mid 14$ 
Meningkatkan Hasil Belajar Dan Keterampilan Generik Sains. Jurnal Inovasi Pendidikan Kimia, 11(2):1979 - 1987.

Pasaribu. I.L dan Simandjuntak. 2005. Sosiologi Pembangunan. Bandung: Tarsito

Rosa, D.D. dan Azizah, U. 2017. Keterampilan Generic Sains Siswa Melalui Penerapan Model Pembelajaran Learning Cycle 7E Pada Materi Laju Reaksi Di SMA Negeri Taman. UNESA Journal of Chemical Education, 6(2):162-167

Suryosubroto. 1997. Proses Belajar-Mengajar di Sekolah. Jakarta: Rineka Cipta.

Susilawati, K., Adnyana, P.B., Swasta, I.B.J. 2014. Pengaruh Model Siklus Belajar 7e Terhadap Pemahaman Konsep Biologi Dan Sikap Ilmiah Siswa. e-Journal Program Pascasarjana Universitas Pendidikan Ganesha, 4: 1-11. 